\title{
Farmers' Participation in Territorial Planning: a Methodological Approach for the Case Study of Huerta De Valencia
}

\author{
Stefano Corsi ${ }^{1, a}$, Chiara Mazzocchi ${ }^{2, b}$, Giovanni Mottadelli ${ }^{1, c}$ and Guido Sali ${ }^{2, d}$ \\ ${ }^{1}$ Department of Economics, Management and Quantitative Methods, via Celoria 2, Milan, Italy \\ ${ }^{2}$ Department of Agricultural and Environmental Sciences, via Celoria 2, Milan, Italy \\ astefano.corsi@unimi.it, ${ }^{b}$ chiara.mazzocchi1@unimi.it, ${ }^{c}$ giovanni.mottadelli@gmail.com, \\ guido.sali@unimi.it
}

Keywords: Participatory Process, Community Planning, Agricultural Multifunctionality, Farmers.

\begin{abstract}
Participation in planning has become progressively important in territory management. As regards Territorial Planning, farmers are among the main stakeholders. In fact multifunctionality of agriculture admits a new role to primary sector. In particular the management of open areas is particularly strategic in peri-urban areas, where competition for resources is highest than in other areas, especially for the land. In this context, the involvement of farmers as privileged stakeholders to land management is even more important. This paper proposes a methodological approach for the evaluation of peri-urban land use plans by farmers, by means of direct surveys on a sample of Spanish farmers. In particular, it has been considered the "Territorial Action Plan of Valencia's Huerta" (TAPVH).
\end{abstract}

\section{Introduction}

Traditional top-down perspectives have turned into support of local participation and integration $[11,12]$ and the participatory process is useful and has many benefits to offer [6]. This shifting focus in policy resumes the growing awareness that nature conservation, quality of life and sustainability of a territory coming from interactions with people [12] and involvement of local stakeholder [3, 1]. As regards Territorial Planning, farmers are among the main stakeholders both in an earliest planning phase and in a last evaluation phase. In fact multifunctionality of agriculture admits a new role to primary sector: on the one hand agriculture produces goods, on the other it produces services. Between these services the role of agriculture in managing open spaces, and consequently farmers' role in land management, is of major importance $[5,10]$. In this sense, participation in planning should extend scientific and technical expertise by adding local experiences, opinion and knowledge as well as the importance of social judgement [6]. Farmers' decisions influence also landscape and although economic theory is used to describe farmers' decision making, it is evident that every modern farmer must act according to their specific options and constraints. This means that producers' strategies doesn't follow the same type of (economic) rationality and value [9] and finally, consequence on landscape could be very different. These differences are also the reason why in planning the direct involvement of farmers is essential, to investigate their opinions and their needs directly. Moreover, participation can also enhances consensus in decisions [2]. In particular the management of open areas is particularly strategic in peri-urban areas, where competition for resources is highest than in other areas, especially for the land. In this context, the involvement of farmers as privileged stakeholders to land management is even more important. This paper proposes a methodological approach for the evaluation of periurban land use plans by farmers. In particular, it has been considered the "Territorial Action Plan of Valencia's Huerta" (TAPVH). Huerta is a peri-urban agricultural area around Valencia, a Spanish city of 800,000 inhabitants; it is a coastal floodplain. It covers a 1'400 $\mathrm{km}^{2}$ surface and its boundaries overlap the municipal borders of four "comarcas"1. Huerta includes 22,000 ha of UAA (Utilized Agricultural Area).

\footnotetext{
${ }^{1}$ Comarcas are administrative aggregations of few ayuntamentos (municipalities) for delivering punctual services to citizens and manage the area. They represent an intermediate administrative level between provinces and municipalities.
} 


\section{Case study}

TAPVH structure has been analyzed; it consists of 5 strategy, that comprehend various objectives to reach by 5 lines of practical actions. Regarding the role of agriculture in territorial planning, the 2nd strategy is strictly related to primary sector and it has been chosen for this analyze . All the strategies are [8]:

- Strategy 1: green infrastructure and open space network;

- Strategy 2: manage and finance agricultural sector; this strategy aims to encourage agricultural multifunctionality, compensate farmers for environmental services, encourages short and quality brand chains, implements agritourism, educational farm,..., ensures agricultural traditions maintenance;

- Strategy 3: landscape integration for infrastructures and urban fringe;

- Strategy 4: protection of cultural and visual heritage;

- Strategy 5: public use model.

As said before, TAPVH identifies 5 lines of action:

- Huerta's legislative protection; this action proposes the adoption of a law protecting agricultural lands from urbanization defending agricultural competitiveness;

○ New agricultural-based management types: for solving agricultural fragmentation and abandonment, lawmaker proposes various solutions for different ownerships. In public agricultural lands, it proposes to rent profitable fields to farmers under certain condition of use and to rent unprofitable fields to citizens for allotment gardens. In private agricultural lands, it proposes, for cultivated lands, a contract of sustainable agricultural management and for abandoned fields the inclusion in "Banco de tierras" project.

- Agricultural competiveness actions include:

- Foundation of Banco de tierras, a project which aims to facilitate meeting of supply and demand in farmland market, under certain conditions of use.

- Promotion of environmentally best practices in agriculture,

- Use of local cultivar to save Huerta biodiversity,

- Implement trade possibilities through direct sale and Huerta quality brand.

- Define open and/or mixed forms of financing; New agricultural, cultural and touristic services (ecosystem services).

\section{Data and methodology}

The aim of the paper is to investigate farmers' opinion on the Territorial Action Plan of Valencia's Huerta (TAPVH) and to gather useful information for improving TAPVH, by a bottom up approach. The methodology chosen is a direct survey focused on Almassera municipality, in Horta Nord comarca; administrative boundaries comprehends 147 ha of UAA, organized in 74 farms. It's a town with 7.250 inhabitants [13], with a population density of $2.646 \mathrm{pop} . / \mathrm{Km}^{2}$ which is higher than comarca's average ${ }^{2}$. Qualitative interviews were carried out on a voluntary basis, using a questionnaire as a trace to guide the survey and to ensure a database of common information. The questionnaire consists of two parts: the first regarding agricultural sector and the second analyzing TAPHV proposals. First section is inspired to questionnaire proposed for VI Italian Agricultural Census [14]. In the second section, using the approach proposed by De Francesco et al. [4], the questionnaire investigates farmers' willingness to participate to sustainable agricultural management contract. Questions regarding opinion on "Banco de tierras" project and direct sale complete the questionnaire. We used a bottom up approach to implement survey, with direct interview to single farmer; this, on one hand, was for stimulating farmers to externalize topics they want to debate and, on other hand, for collecting meaningful data.

${ }^{2} 1,285$ pop. $/ \mathrm{km}^{2}$ 


\section{Results}

Interview time vary from 30 and 45 minutes. Our sample is composed by 20 farmers. The first results are about agricultural structure are that the farmers' average age is 55 years, and each of these has a farm average surface around about 4 ha, where the main crops are chufa ${ }^{3}$, potato and onion, which occupy $66 \%$ of Huerta's UAA. As regards the management typology (Table 1), $90 \%$ are professional farmers , 5\% are part-time farmers and 5\% are hobby farmers, with a land's ownership divided between a $61 \%$ of farmer's property lands, a $34 \%$ of rented lands and a $5 \%$ of loaned lands. Moreover, the $50 \%$ of the sample didn't attend any professional or high school, showing a low study level; only the $5 \%$ of farmers reached an agricultural degree.

Table 1.Farms management typology.

\begin{tabular}{|l|r|}
\hline \multicolumn{1}{|c|}{ Management type } & respondents \\
\hline Professional farmer without farmhands & $65 \%$ \\
\hline Professional farmer with farmhands & $25 \%$ \\
\hline Part-time farmer & $5 \%$ \\
\hline Hobby farmer & $5 \%$ \\
\hline Total & $100 \%$ \\
\hline
\end{tabular}

Table 2.Farmers' participation in agricultural associations.

\begin{tabular}{|l|r|}
\hline \multicolumn{1}{|c|}{ Agricultural associations } & respondents \\
\hline Community of irrigators & $54 \%$ \\
\hline Agricultural council & $46 \%$ \\
\hline Labour union & $15 \%$ \\
\hline Cooperative & $15 \%$ \\
\hline Nothing & $23 \%$ \\
\hline Total & $100 \%$ \\
\hline
\end{tabular}

Participation in agricultural associations (Table 2) is diffused (85\%); community of irrigators (35\%) and agricultural council (30\%) are the most frequented, thanks to their implications in irrigation rights and lobbying activity for agricultural sector. The question about the future of agricultural activity shows a majority of negative responses: $52 \%$ of the sample expects a cessation of their activity, both for lack in profitability and in generational replacement; $27,5 \%$ foresees a continuation of the activity and $17 \%$ forecast a continuation with new investments. As regards TAPHV evaluation, main results are the following:

- "Banco de tierras": the initiative had scarce success among farmers, perhaps because it is perceived as an additional "control element" that limits their decision making power. The purpose of the initiative had farmers' approval, but proposal of implementation do not meet farmers' needs. A greater agreement is collected in cultivating lands rented through this project ( $35 \%$ favorable).

- Implementation of farmers training through participation in specific courses has a scarce success. This can be caused by a low participation rate detected ( $75 \%$ don't participate) in the last 2 years. An opportunity rised during the survey can be the habit to debate over crop practices among farmers (70\% frequently, $20 \%$ sometimes, $10 \%$ never);

- Sustainable agricultural management contract, which aims to implement good agricultural and environmentally-friendly practices, receives moderate interest among respondents. It's conceivable high presence of passive participants [7] whose adhere only for economic reasons; this is suggested by higher rates of answers at economic compensation question rather than to environmental protection questions. The $67 \%$ of measures is judged implementable; lower values of feasibility are detected for environmental restoration and management of natural heritage. In general, measures regarding crop techniques and local varieties are preferred to the ones concerning public and recreational use of Huerta.

\footnotetext{
${ }^{3}$ A typology of spanish cultivated tuber, Chufa valenciana POD.
} 
- Promotion of local varieties receives scarce interest among respondents, because many farmers raised doubts about acknowledgement, both legal than monetary. Introduction of a quality brand can be a possible solution, but its implementation should involve farmers.

- Direct sale is practiced by 35\% of farmers. Direct sales obtains a double price respect selling to big trade companies. Nonetheless farmers' declares to need a bureaucratic simplification of procedures, as emerges from survey;

- Production planning based on the market demand is well accepted by farmers.

\section{Conclusions}

In conclusion, farmers show many doubts about TAPHV development strategy and actions, probably because they were not involved in the drafting of the plan. For different reasons many proposals are considered uninteresting or even non-functional to the revival of the agricultural sector. It is essential to involve farmers in planning with bottom-up strategies, although this requires a lot of resources, including the financial one, and often it is difficult to involve a relevant number of them. In this sense the information could be partial, although diffusion of informatics among farmers, allows the possibility to collect more meaningful results with a higher dimension of the sample. One of the most interesting results is the opinion of farmers about the future of agriculture itself and the changes that will happen in the primary sector. In this case, high tendency to interact among farmers and high participation to agricultural associations denote a wish to participate actively in decisional process. This can be implemented with negotiation tables to debate over proposal and make lobby actions to revival agriculture and better manage territory in periurban areas.

\section{References}

[1] T. C.Beierle, D. M.Konisky: Values, conflict and trust in participatory environmental planning, in: Journal of Policy Analysis and Management Vol. 19, No. 4, (2000), p. 587-602

[2] A. Bond, J. Palerm, P. Haigh: Public participation in EIA of nuclear power plant decommissioning projects: a case study analysis, in: Environmental Impact Assessment Review, No. 24, (2004), pp. 617-641

[3] D. Corvi, F. Sacchi: Prove di governo metropolitano, in: Urbanistica informazioni (2012), pp. 245-246

[4] E. Defrancesco, P. Gatto, F. Runge, S. Trestini: Factors affecting farmers' participation in agri-environmental measures: a northern Italian perspective, in: Journal of agricultural economics, Vol. 59, No. 1, (2008), pp. 114-131

[5] C. Mazzocchi, G. Sali, S. Corsi: Land use conversion in metropolitan areas and the permanence of agriculture: Sensitivity Index of Agricultural Land (SIAL), a tool for territorial analysis, in: Land Use Policy, No. 35, (2013), pp. 155-162

[6] J. Milligan, T. O’ Riordan, S. A. Nicholson-Cole, A. R. Watkinson: Nature conservation for future sustainable shorelines: lessons from seeking to involve the public, in: Land Use Policy, No. 26, (2009), pp. 203-213

[7] C. Morris, C. Potter: Recruiting the new conservationists: farmers' adoption of agrienvironmental schemes in the U.K., in: Journal of Rural Studies, Vol. 11, (1995), pp. 51-63

[8] A. Muñoz Criado: Plan de la Huerta de Valencia, un paisaje milenario, Laimprenta CG, Spain (2006)

[9] J. Primdahl: Agricultural landscapes as places of production and for living in owner's versus producer's decision making and the implications for planning, in: Landscape and Urban Planning, No. 46, (1999), pp. 143-150 
[10] G. Sali, S. Corsi, C. Mazzocchi: Rural development policies and land use change: the Lombardy case study. Book 1 I 135 - 141. Proceedings of the 6th International Scientific conference "Rural Development 2013". ISSN 2345-0916 online, ISSN 1822-3230 print

[11] A. Scott, P. Shannon: Local landscape designations in Scotland: opportunity or barrier to effective landscape management, in: Landscape and Urban Planning, No. 81, (2007), p. 257269

[12] M. Stenseke: Local participation in cultural landscape maintenance: lessons from Sweden, in: Land Use Policy, No. 26, (2009), pp. 214-223

[13] Information on http://www.ine.es

[14] Information on http://www3.istat.it/censimenti/agricoltura2010/questionario.pdf 